\title{
Demography and feeding behavior of Stenostomum leucops (Dugés, 1828)
}

\author{
Alma R. NÚÑEZ-ORTIZ, Sarma NANDINI, ${ }^{*}$ S.S.S. SARMA
}

Laboratorio de Zoología Acuática, Unidad de Morfofisiología, Facultad de Estudios Superiores Iztacala, Universidad Nacional Autónoma de México, Av. de los Barrios No. 1, Los Reyes, CP 54090 Iztacala, Tlalnepantla, Mexico

*Corresponding author: nandini@unam.mx

\begin{abstract}
Freshwater turbellarians, despite their mainly benthic habits, interact with pelagic communities of rotifers and cladocerans. However, very little is known about their demographic characteristics, food preference and functional response. To fill that gap we studied one of the most widely spread species, Stenostomum leucops. We conducted population growth experiments using abundant food (several rotifer and cladocerans species). To evaluate possible impact of $\mathrm{S}$. leucops on planktonic communities, we conducted prey preference experiments at two temperatures: 18 and $23^{\circ} \mathrm{C}$. The number of rotifers and cladocerans consumed was calculated by the difference between the initial and final density. We found that diets supplemented with fresh algae achieved higher $\mathrm{S}$. leucops densities than those with detritus supplements in their diets. In the case of animal diets, Euchlanis dilatata allowed $\mathrm{S}$. leucops reach higher densities than the other zooplankton species; E. dilatata was positively selected for in the selectivity study at both 18 and $23^{\circ} \mathrm{C}$. Stenostomum leucops showed a type II functional response on rotifers and the cladoceran Alona glabra. Our results suggest that $\mathrm{S}$. leucops select their prey according to their vulnerability using different mechanisms, which optimize their food intake.
\end{abstract}

Key words: Stenostomum; functional responses; population growth; prey selection; feeding behavior.

Received: April 2015. Accepted: October 2015.

\section{INTRODUCTION}

Freshwater turbellarians can be found in headwater streams to large rivers and in wetlands to large lakes where they are part of the bottom, surface and interstitial benthos (Schwartz and Hebert, 1982; Blaustein and Dumont, 1990). They can also be found in very small streams and brooks or on different types of substrates (e.g., moss, vascular plants, wood snags, detritus, gravel, or sand) in the littoral areas of rivers (Noreña et al., 2005). Littoral species of lotic and lentic environments, inhabitants of plant roots, leaves, and surface sediments (i.e., the first $\mathrm{cm}$ ) are subject to disturbances during the different seasons due to changes in the water level. This fact causes great oscillations in the abundance dynamics of species (Threlkeld, 1994) and their ability to swim in the water column (Trochine et al., 2006), allow them to interact with the zooplankton community. Their diet includes a wide variety of unicellular organisms and invertebrates especially bacteria, ciliates, rotifers and cladocerans (Nandini et al., 2011; Hammill et al., 2015). Thus, they play an important role in structuring the ecological community and in recycling nutrients to higher trophic levels. Turbellarians have been a neglected group of organisms in ecological research although, it is estimated that there are over 200 species in lotic waters in the world with densities up to 40,000 ind. $\mathrm{m}^{-2}$ (Kolasa and Tyler, 2010). However, their identification is difficult, especially due to the paucity of trained taxonomists.
Most studies on flat worms are aimed at regeneration (Reddien and Alvarado, 2004; Cebrià and Newmark, 2005; Bely and Sikes, 2010), senescence (Martinez and Levinton, 1992; Mouton et al., 2009) and stem cells subjects (Reuter and Kreshchenko, 2004). Most turbellarians have neoblasts (Newmark and Alvarado, 2000) which allow them to be good models for this type of research. Neoblasts also allow these multicellular organisms to reproduce asexually, primarily by transverse fission, which complicates the study of their demographic characteristics, whereby these studies are scarce and the data are highly variable (Egger et al., 2007; Mouton et al., 2009; Dunkel et al., 2011).

Biotic interactions, especially those related to feeding and competition, are essential in structuring aquatic communities. These interactions depend on several factors: density of organisms (Chesson, 1986), their biological characteristics (Iyer and Rao, 1996; Lampert and Sommer, 2007) and spatial distribution (Dutilleul, 1993). In predator-prey relationships changes in prey density result in two types of responses of the predator: numerical and functional (Case, 2000). The first involves changes in predator density and the second, adjustments in their feeding rates; both related to prey type and availability (Case, 2000). In the case of some non-generalist predators, life cycles of prey and predator are often linked (Murdoch and Bence, 1987). These responses have been observed in few freshwater flatworms such as 
Mesostoma lingua (Dumont and Schorreels, 1990) and Stenostomum virginianum (Kratina et al., 2009).

Some biological characteristics have an influence on predator-prey relationship, for instance: morphology, motion, prey size, and the predation mechanisms (Werner and Hall, 1976; Iyer and Rao, 1996; Lampert and Sommer, 2007). Turbellarians use various mechanisms to capture their prey, including: active search, sit and wait, toxins release or secretion of mucus traps (Blaustein and Dumont, 1990). For example, it has been shown that Mesostoma lingua is able to prey on Daphnia magna releasing a toxic mucus trap that paralyzes the prey, and then, engulfs it with the ventral area of its body and sucks the prey (Dumont and Carels, 1987). The spatial distribution of predator and prey is important because it controls the probability of encounter with each other (Dutilleul, 1993); organisms sharing the same habitat, have more probabilities of encounters (Gilinsky, 1984). However, it has been reported that $M$. ehrenbergii is able to capture evasive prey that inhabit different habitats, such as the copepods Boeckella gracilis and Acanthocyclops robustus, using mucus traps (Trochine et al., 2006), and if the worm is very hungry, it can swim very fast, searching for its prey (De Meester and Dumont, 1990). Turbellarians are carnivorous, but their diet also includes algae; maybe to satisfy their eicosapentaenoic acid requirements. Eicosapentaenoic acid is important for growth and reproduction; but most of animals are unable to synthesize it, and must be obtained it from their diet (Wacker and Martin-Creuzburg, 2007); moreover, detritus can be an alternative source, even if quality of fatty acids and nutrients are less than in fresh algae (Perhar and Arhonditsis, 2009), it could be important because in the case of flatworms, this resource would be more available in its preferred benthic habitat. Turbellarians are involved in top-down regulation, being predators; but they are also prey, some of their predators are fishes such as Poecilia vivipara and $P$. reticulata; (Dumont et al., 2014) and the predatory ciliate Dileptus margaritifer (Buonanno, 2009).

Given the potential growth of Stenostomum populations, we aimed at to explore their possible impact on prey by quantifying the growth and consumptions rates of S. leucops on selected prey species. In this work, we present data on the population growth on different diets and the feeding behavior of Stenostomum leucops (Dugès, 1828) widely distributed in America (Noreña et al., 2005) that can produce changes in morphology, behavior, physiology and life history of its prey. We used littoral prey with different characteristics with respect to morphology, movement, size and habitat; including the rotifers Euchlanis dilatata, Plationus patulus, Lecane bulla, and the cladocerans Alona glabra, Moina macrocopa and Macrothrix triserialis; the diets were supplemented with fresh algae or detritus.

\section{METHODS}

\section{Cultures}

Stenostomum leucops was isolated from a pond in the State of Veracruz (Mexico) in 2005 and has been cultured in moderately hard water (EPA; Weber, 1993) on a mixture of zooplankton for several years in our laboratory. We fed S. leucops using rotifers (Plationus patulus, Euchlanis dilatata) and cladocerans (Alona glabra and Macrothrix triserialis) ad libitum. Cladocerans and rotifers were grown in EPA medium and fed Scenedesmus acutus. Cell density was measured using a hemocytometer and the density offered to zooplankton was $1 \times 10^{6}$ cells $\mathrm{mL}^{-1}$. The medium was changed twice a week.

\section{Population growth}

We selected similar size worms for all experiments. All the experiments were performed in Petri dishes, where we put 2 worms and $15 \mathrm{~mL}$ of EPA medium with $S$. acutus, live or in detrital form. To prepare detritus, we enumerated cell density of $S$. acutus which was kept for four days in darkness at $30^{\circ} \mathrm{C}$ following Gulati et al. (2001).

Two individuals of $S$. leucops were placed in each Petri dish and were offered seven different diets: a ciliate (Paramecium sp.), rotifers (P. patulus, E. dilatata, Lecane bulla) and cladocerans (A. glabra, M. triserialis and Moina macrocopa). The densities were 4 ind. $\mathrm{mL}^{-1}$ for Paramecium sp.; 2 and 1 ind. $\mathrm{mL}^{-1}$ for rotifers and cladocerans, respectively. We estimated daily the density of the organisms using a stereomicroscope. Rotifers and cladocerans were replaced to maintain the initial density. The medium was changed twice a week. The growth rate $\left(\right.$ day $\left.^{-1}\right)$ for each population was calculated using the exponential growth equation (Case, 2000):

$$
r=\frac{\ln N_{t}-\ln N_{0}}{t}
$$

where

$r$, rate of population increase;

$N_{0}$ and $N_{t}$, initial and maximum population densities, respectively;

$T$, is the day on which the maximum density is reached.

We compared the growth rates $(r)$ of S. leucops on different diets using one and two-way ANOVA (Sigma-Plot ver. 11).

\section{Feeding preference}

The experiments were conducted at two temperatures: 18 and $23^{\circ} \mathrm{C}$. Before experiments, each turbellarian was starved for $3 \mathrm{~h}$ and acclimated to the respective temperature. Each Petri dish contained $15 \mathrm{~mL}$ of EPA medium and P. patulus, E dilatata, Lecane bulla (15 individuals of each species) and A. glabra, M. triserialis and Moina 
macrocopa (5 individuals of each species). The feeding time was $2 \mathrm{~h}$. The consumption of each prey species was calculated by the difference between the initial and final densities. For the selectivity index, $\alpha$ Manly (Krebs, 1999) was used:

$a_{i}=\frac{\hat{r}_{i}}{\hat{n}_{i}}\left(\frac{1}{\Sigma\left(\hat{r}_{j} / \hat{n}_{j}\right)}\right)$

where

$\hat{a}_{i}$, Manly's $\alpha$ for prey type i;

$\hat{r}_{i}, \hat{r}_{j}$, proportion of prey type $i$ or $j$ in the $\operatorname{diet}(i \mathrm{y} j=1,2$, $3, \ldots, \mathrm{m})$;

$\hat{n}_{i}, \hat{n}_{j}$, proportion of prey type $\mathrm{i}$ or $\mathrm{j}$ in the environment;

$\mathrm{m}$, number of types of possible prey.

\section{Functional response}

Five densities were used: $0.5,1,2,5$ and 10 ind $\mathrm{mL}^{-1}$ in the case of rotifers ( $P$. patulus, $E$ dilatata, Lecane bulla); and $0.2,0.5,1,2$ and 5 ind. $\mathrm{mL}^{-1}$ in the case of cladocerans (A. glabra, M. triserialis and Moina macrocopa). Each Petri dish containing $15 \mathrm{~mL}$ of EPA medium, 2 worms (starved for $3 \mathrm{~h}$ ) and the chosen prey. Feeding time was $2 \mathrm{~h}$ after which the prey remained in the Petri dish were fixed using $4 \%$ formalin. The number of rotifers and cladocerans consumed was calculated by the difference between the initial and final density. The obtained data were transformed using the Michaelis-Menten equation (Lampert and Sommer, 2007)

$V_{0}=\frac{V_{\max } S}{K_{m}+S}$

where

$V_{0}$, consumption rate;

$V_{\max }$, saturation value of the rate of consumption;

$S$, prey availability;

$K_{m}$, prey density at wich $V_{\max } /{ }_{2}$ was reached.
In order to determine the type of functional response, data was linearized by the equation of the proportion of ingested prey (Trexler et al., 1988): $\mathrm{d}=\mathrm{PR} / N o$, where $P R=$ predation rate; and $N_{0}=$ initial number of prey.

\section{RESULTS}

Stenostomum leucops increased in abundance on diets involving fresh algae but a decreased on diets supplemented with detritus. The experimental duration was 35 days, by which time population densities had reached a peak and then began to decline. The maximum densities were reached between days 11 to 30 , but in most treatments they reached maximum densities at day 18 . For rotifers as prey, we observed that $S$. leucops reached higher abundances on E. dilatata than on P. patulus or Lecane bulla, in both cases, with fresh algae or detritus. Among cladocerans, population densities were highest on A. glabra and M. macrocopa supplemented with fresh algae rather than detritus (Fig. 1).

The range for the rate of population increase $r$ varied from -0.69 and 0.141 day $^{-1}$, depending on the diet. Regardless of the prey species fresh algae in the medium allowed $S$. leucops obtain a higher $r$ than detritus. The population growth rates were negative on diets of Paramecium sp. $+S$. acutus and Paramecium sp.+detritus (Fig. 2); these diets had a significant effect on the $r$ value $(\mathrm{P}<0.05$, F-test, oneway ANOVA, Tab. 1). For diets of algae and rotifer or cladocerans, both type of rotifer $(\mathrm{P}<0.01)$ and cladoceran species had a significant effect $(\mathrm{P}<0.05)$ on $r$ values $(\mathrm{F}$ test, two-way ANOVA, Tab. 1).

Data from the prey selectivity experiments showed that among the zooplankton species, at prey density tested, E. dilatata and L. bulla were positively selected in both temperatures but P. patulus was avoided. At $18^{\circ} \mathrm{C} \mathrm{S}$. leucops also consumed $M$. triserialis but at $23^{\circ} \mathrm{C}$ none of the cladocerans was selected and preference for $E$. $d i$ latata increased (Fig. 3).

Tab. 1. Results of one and two-way analysis of variance performed on the $r$ values of $S$. leucops feeding with different algal and animal diets.

\begin{tabular}{|c|c|c|c|c|c|c|}
\hline & Source of variation & DF & SS & MS & F & $\mathbf{P}$ \\
\hline One-way ANOVA S. acutus-Paramecium sp. & $\begin{array}{l}\text { Between groups } \\
\text { Residual } \\
\text { Total }\end{array}$ & $\begin{array}{l}1 \\
5 \\
6\end{array}$ & $\begin{array}{c}0.0220 \\
0.00294 \\
0.0249\end{array}$ & $\begin{array}{c}0.0220 \\
0.000589\end{array}$ & 37.349 & 0.002 \\
\hline Two-way ANOVA algal diet-rotifer & $\begin{array}{l}\text { Algae type (fresh or detritus) } \\
\text { Rotifer species } \\
\text { Algae type x Rotifer } \\
\text { Residual } \\
\text { Total }\end{array}$ & $\begin{array}{c}1 \\
2 \\
2 \\
17 \\
22\end{array}$ & $\begin{array}{c}0.0507 \\
1.850 \\
0.0843 \\
0.119 \\
2.239\end{array}$ & $\begin{array}{c}0.0507 \\
0.925 \\
0.0422 \\
0.00697 \\
0.102 \\
\end{array}$ & $\begin{array}{c}7.268 \\
132.675 \\
6.049\end{array}$ & $\begin{array}{c}0.015 \\
<0.001 \\
0.010\end{array}$ \\
\hline Two-way ANOVA algal diet - Cladocera & $\begin{array}{l}\text { Algae type (fresh or detritus) } \\
\text { Cladocera } \\
\text { Algae type x Cladocera } \\
\text { Residual } \\
\text { Total }\end{array}$ & $\begin{array}{c}1 \\
2 \\
2 \\
16 \\
21\end{array}$ & $\begin{array}{l}0.201 \\
0.289 \\
0.304 \\
0.612 \\
1.493\end{array}$ & $\begin{array}{c}0.201 \\
0.144 \\
0.152 \\
0.0383 \\
0.0711\end{array}$ & $\begin{array}{l}0.036 \\
0.045 \\
0.040\end{array}$ & \\
\hline
\end{tabular}

$D F$, degrees of freedom; SS, sum of squares; $M S$, mean square; F, F-ratio. 

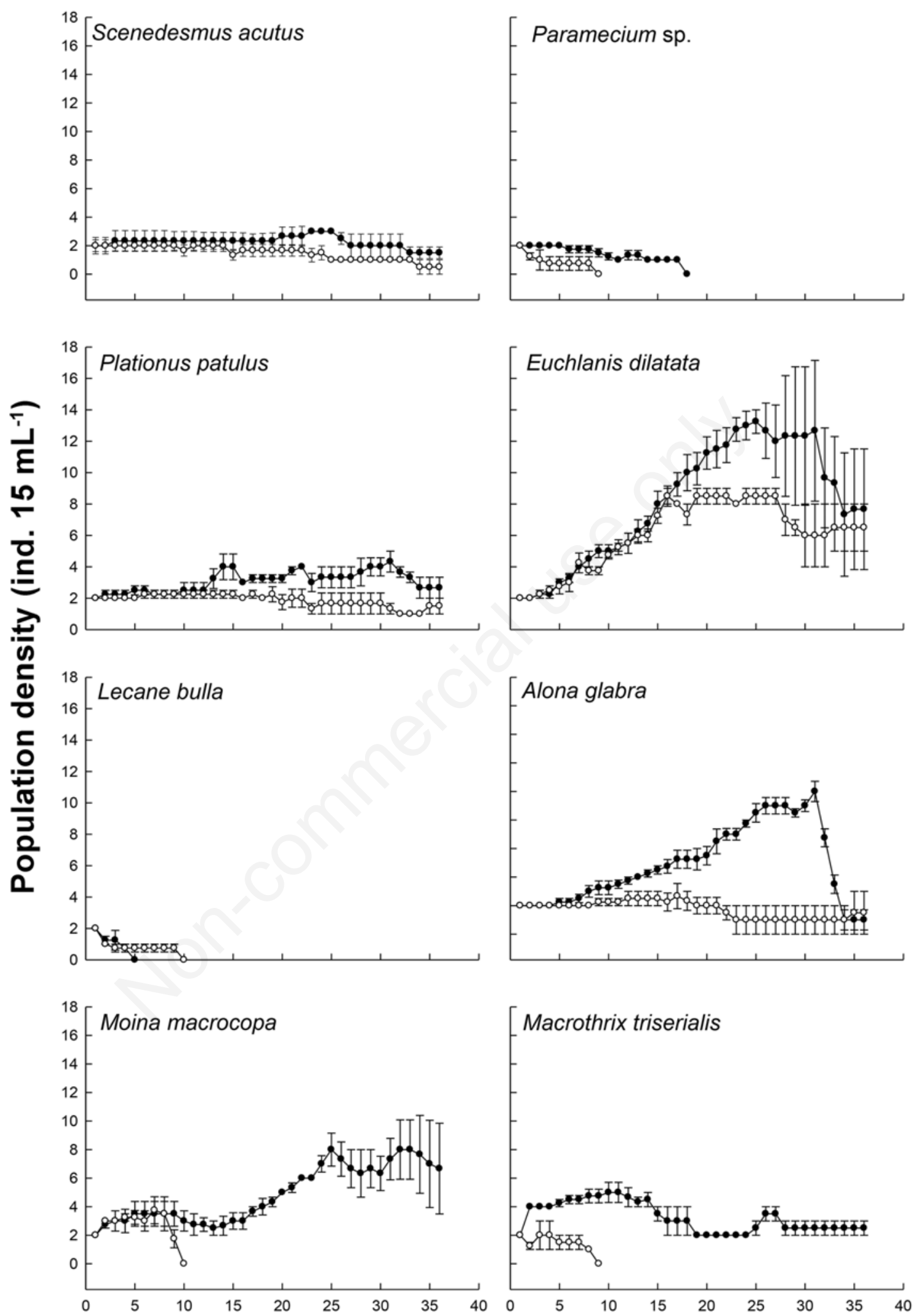

Time (days)

Fig. 1. Population growth of S. leucops offered: a) S. acutus; b) detritus; c) P. patulus with S. acutus; d) P. patulus with detritus; e) E. dilatata with $S$. acutus; f) E. dilatata with detritus; g) A. glabra with $S$. acutus; h) A. glabra with detritus. Shown are mean \pm SE based on four replicate observations. 
Functional response curves showed increased prey consumption with increasing prey density in the medium (Fig. 4). In general, changes in temperature did not have a significant impact with respect to prey consumption. The maximum number $( \pm \mathrm{SD})$ of rotifers prey consumed by $S$. leucops during $2 \mathrm{~h}$ feeding, were $8.75 \pm 3.8$ at $23^{\circ} \mathrm{C}$ for $E$. dilatata, $10.87 \pm 2.4$ at $18^{\circ} \mathrm{C}$ for $P$. patulus and $5.75 \pm 0.9$ at $18^{\circ} \mathrm{C}$ for L. bulla. When $A$. glabra as prey, the maximum prey consumed was $3.33 \pm 0.29$ at $18^{\circ} \mathrm{C}$.

\section{DISCUSSION}

Turbellarians are involved in structuring zooplankton communities through modifying directly and/or indirectly the morpho-physiological or demographic characteristics of organisms (Hammill et al., 2015). They could be a link in channelizing energy between the pelagic and benthic zones but there are few studies on the interaction of organisms from both zones (Threlkeld, 1994). Published data suggest that an increase in density of flatworms leads to decreased zooplankton such as Daphnia and Bosmina (Caramujo and Boavida, 2000), and Moina (Blaustein and Dumont, 1990). In this study we observed highest densities of $S$. leucops on E. dilatata and A. glabra, both species share a similar habitat of littoral regions of water bodies as the worm (Kolasa and Tyler, 2010). It appears that the spines of the rotifer P. patulus and the cladoceran $M$. triserialis are effective defenses since the population growth rate of the worms was considerably lower on these prey. Stenostomum leucops has a simple pharynx without much capacity for expansion. In some other invertebrate predators such as Asplanchnopus multiceps fed P. patulus and $M$. triserialis, the growth rates were low (Nandini and

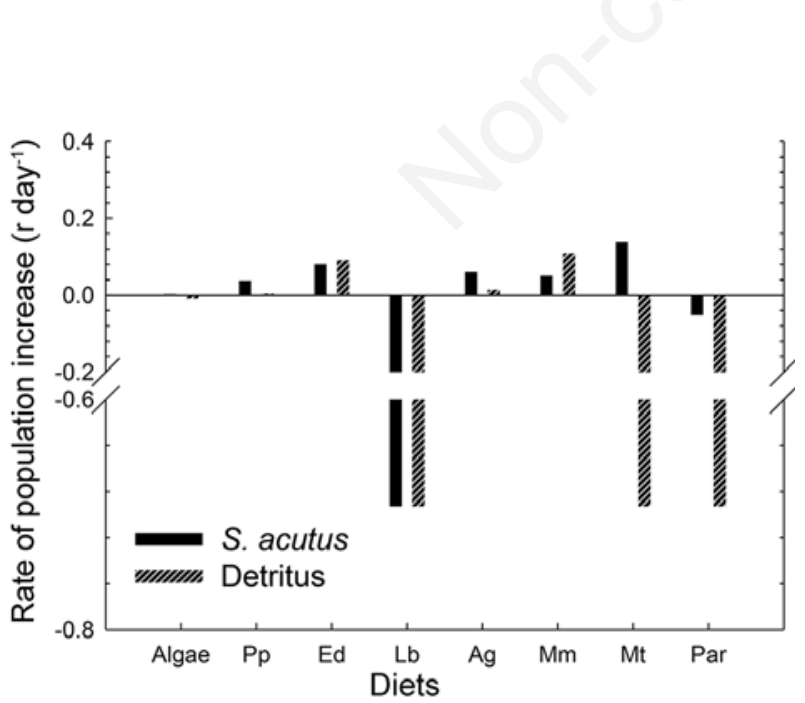

Fig. 2. $\mathrm{r}$ values of $S$. leucops offered six diets. Sa, S. acutus; D, detritus; $\mathrm{Pp} / \mathrm{Sa}$, P. patulus/S. acutus; $\mathrm{Pp} / \mathrm{D}$, P. patulus/detritus; $\mathrm{Ed} / \mathrm{Sa}$, E. dilatata/S. acutus; Ed/D, E. dilatata/detritus; $\mathrm{Ag} / \mathrm{Sa}$, A. glabra/S. acutus; Ag/D, A. glabra/ detritus. Mean values $\pm \mathrm{SE}$ based on four replicate observations are shown.
Sarma, 2005). Although it is assumed that turbellarians grow well on detritus and/or protozoan diets, we did not find this trend in this study. This could be due to the low carbon content of the diet and the lack of nutrients; in nature the turbellarians need be exposed to a richer and more varied detrital diet.

The peaks of maximum density achieved by Stenostomum were low compared with other smaller worms (Kolasa and Tyler, 2010) most probably due to its mode of reproduction which is transverse paratomy. The highest densities of $S$. leucops were reached when their diet was supplemented with fresh algae but not detritus, probably because of the poor nutritional quality of the latter (Sterner and Hessen, 1994). Nutritional value of these resources is reflected in the somatic phosphorus content and composition of fatty acids (DeMott and Pape, 2005; Arndt and Sommer, 2014). Paramecium sp. allowed S. leucops survive just less than 20 days, even though these heterotrophic flagellates include in their natural diet (Vera et al., 2001), participating in the transfer of energy. However, it appears that they are not a good source of nutrients. It has been shown that ingesting

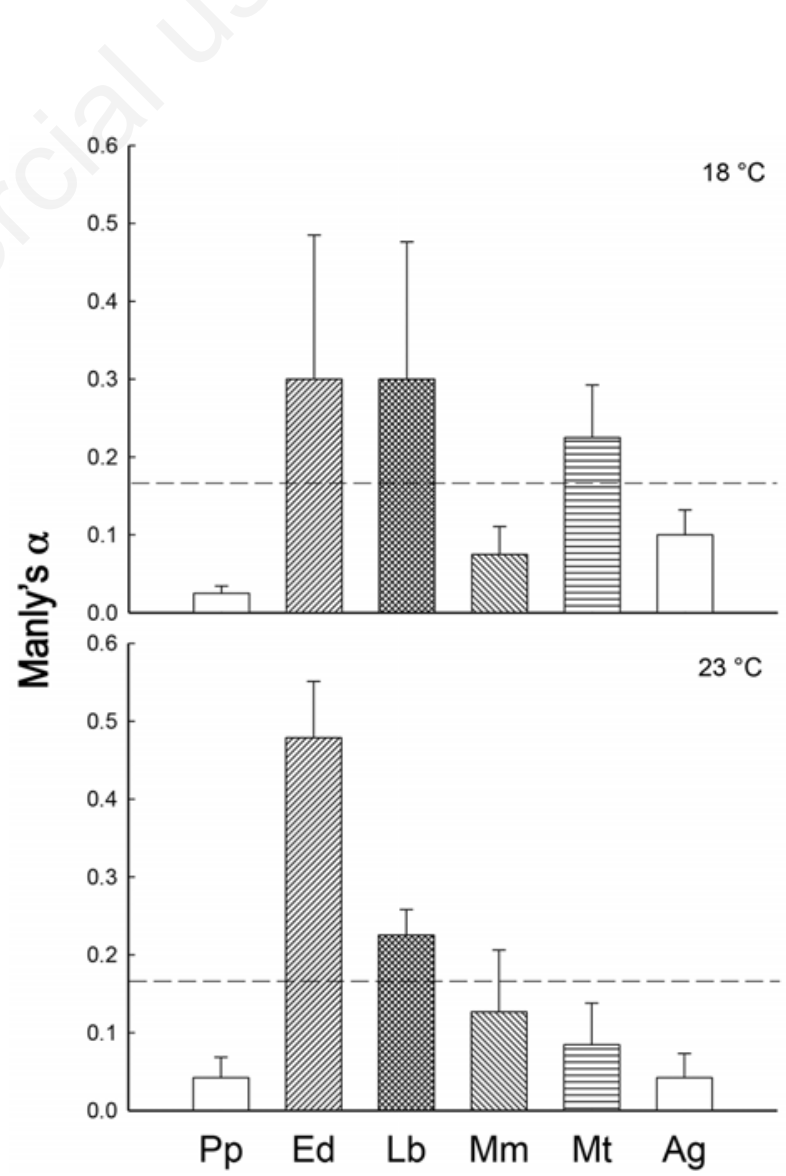

Fig. 3. Feeding preference of $S$. leucops offered six prey types at two temperatures: a) $18^{\circ} \mathrm{C}$; and b) $23^{\circ} \mathrm{C}$. Pp, P. patulus; Ed, E. dilatata; Lb, L. bulla; Mm, M. macrocopa; Mt, M. triserialis; $\mathrm{Ag}$, A. glabra. The Manly's $\alpha$-values (mean $\pm \mathrm{SE}$ ) based on four replicate observations) are shown. 

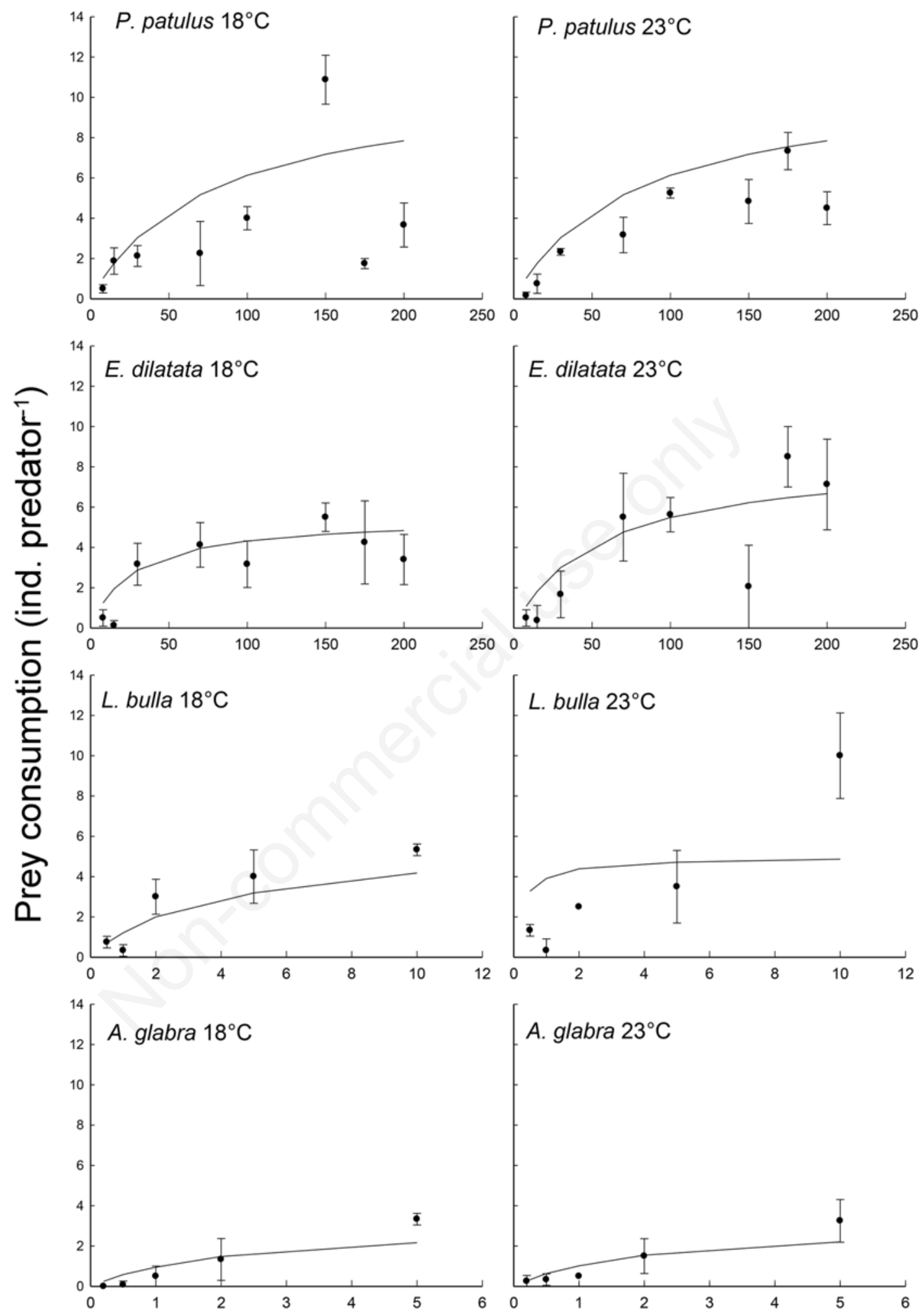

\section{Prey density (ind. $15 \mathrm{~mL}^{-1}$ )}

Fig. 4. Functional response of $S$. leucops offered four preys at two temperatures: a) $P$. patulus at $18^{\circ} \mathrm{C}$; b) $P$. patulus at $23^{\circ} \mathrm{C}$; c) $E$. dilatata at $18^{\circ} \mathrm{C}$; d) E. dilatata at $23^{\circ} \mathrm{C}$; e) L. bulla at $18^{\circ} \mathrm{C}$; f) L. bulla at $23^{\circ} \mathrm{C}$; g) A. glabra at $18^{\circ} \mathrm{C}$; h) A. glabra at $23^{\circ} \mathrm{C}$. The mean $\pm \mathrm{SE}$ values of the actual prey consumed based on four replicate observations, and the transformation of the curve using the MichaelisMenten equation are shown. 
Paramecium allows predators satisfy their metabolic demands but the carbon input is insufficient to permit adequate reproduction in cladocerans, copepods and rotifers (De Biase et al., 1990; Mohr and Adrian, 2002). The quality of the different diets was reflected in the turbellarian population growth even when the diet consisted only of algae or detritus; this suggests that $S$. leucops acquires different nutrients, the availability of which, in turn, affects its demographic parameters.

The energy designated for reproduction depends on the amount of food available and consumed (Sarma and Rao, 1991) which, in turn, depends on the vulnerability of the prey. Vulnerability is affected by characteristics such as size, presence of spines, swimming behavior, etc. (Iyer and Rao, 1996). These characteristics affect directly the prey selection by the predator; but also affect the functional response; which helps us understand how a predator plays a role in structuring prey populations. In the food preference experiment, we observed that in both temperatures $S$. leucops prefer $E$. dilatata compared to other prey; probably because $E$. dilatata is an organism with benthic habits. Among the rotifers offered, E. dilatata is the fastest achieving speeds up to $0.98 \mathrm{~mm} \mathrm{~s}^{-1}$ (Rico-Martínez and Snell, 1997), but despite this, probably the hungry turbellarian is able to swim faster to capture this spineless prey easily. P. patulus was not positively selected at any temperature even though its speed $\left(0.69 \mathrm{~mm} \mathrm{~s}^{-1}\right)$ is lower than that of E. dilatata as it has numerous anterior (10) and posterior spines (4), features not present in $E$. dilatata and $L$. bulla. Although it was surprising to note that the flatworm did not prefer and neither did it grow well on the seemingly defenseless Lecane bulla similar trends are not uncommon in other invertebrate predators (Iyer and Rao, 1996). On the other hand our results indicate that it is not easy to extrapolate findings from preference studies to possible growth patterns. Although M. triserialis was the only cladoceran positively selected, the growth of the turbellarian on this species was low as compared to M. macrocopa and A. glabra perhaps because the feeding time was only two hours and it was observed that S. leucops tends to prey on larger organisms (such as cladocerans).

We observed that the number of prey items consumed increased with increasing prey density. The asymptote was achieved with prey such as $P$. patulus and E. dilatata, but not in the case of A. glabra. In the case of A. glabra consumption was very low, probably due to its size, and ornamentation that can modify handling time, capture and ingestion and decreasing consumption rates. For Mesostoma lingua a maximum intake of between 4 and 5 Daphnia per day, on a density of 10 daphniids per day (Dumont and Schorreels, 1990; Schwartz and Herbert, 1982); and in the case of $S$. leucops it was observed that the maximum density of cladocerans (Alona $70 \mathrm{~mL}^{-1}$ ) per capita consumption was $3.25 \mathrm{~A}$. glabra in $2 \mathrm{~h}$. The effectiveness of predator depends on many factors which have not yet been analyzed, such as the ability to form groups to hunt which reduces per capita consumption or slow hunting speeds (Kratina et al., 2009). We also observed a general increase in prey consumption with increasing temperature, most probably to meet the increased metabolic demands (Lampert and Sommer, 2007).

\section{CONCLUSIONS}

Our study showed that $S$. leucops could have an important role regulating the population density of their prey, influenced by the selectivity of the predator and vulnerability of the prey (Lampert and Sommer, 2007). Our observations suggest that turbellarians may play an important role in transferring energy to higher trophic levels especially under conditions in which rotifers and cladocerans face competitive stress for limiting food or space habitats and predation as a result of fish or amphibian breeding.

\section{ACKNOWLEDGMENTS}

The first author thanks the financial assistance obtained from Consejo Nacional de Ciencia y Tecnología for a doctoral scholarship (233847) and the Posgrado en Ciencias Biológicas, UNAM . SN and SSSS thank Consejo Nacional de Ciencia y Tecnología for SNI support (20520 and 18723).

\section{REFERENCES}

Arndt C, Sommer U, 2014. Effect of algal species and concentration on development and fatty acid composition of two harpacticoid copepods, Tisbe sp. and Tachidius discipes, and a discussion about their suitability for marine fish larvae. Aquacult. Nutrition 20:44-59.

Bely AE, Sikes JM, 2010. Acoel and platyhelminth models for stem-cell research. J. Biol. 9:14-18.

Blaustein L, Dumont HJ, 1990. Typhloplanid flatworms (Mesostoma and related genera): mechanisms of predation and evidence that they structure aquatic invertebrate communities. Hydrobiologia 198:61-77.

Buonanno F, 2009. Antipredator behavior of the freshwater Microturbellarian Stenostomum sphagnetorum against the predatory ciliate Dileptus margaritifer. Zool. Sci. 26:443-447.

Case TJ, 2000. An illustrated guide to theoretical ecology. Oxford: Oxford University.

Caramujo MJ, Boavida MJ, 2000. Dynamics of Daphnia hyalina $\times$ galeata in Castelo-do-Bode Reservoir: The effect of food availability and flatworm predation. Aquat. Ecol. 34:155-163.

Cebrià F, Newmark PA, 2005. Planarian homologs of netrin and netrin receptor are required for proper regeneration of the central nervous system and the maintenance of nervous system architecture. Development 132:3691-3703.

Chesson PL, 1986. Environmental variation and the coexistence species, P. 240-256. In: J. Diamond J. and T. Case (eds.), Community Ecology. Harper \& Row, New York. 
DeBiase AE, Sanders RW, Porter KG, 1990. Relative nutritional value of ciliate protozoa and algae as food for Daphnia. Microbial Ecol. 19: 99-210.

De Meester L, Dumont HJ, 1990. Laboratory observations on the vertical distribution of a tropical pelagic flatworm (Mesostoma sp.) in relation to satiation. Hydrobiologia 198:103-106.

DeMott WR, Pape BJ, 2005. Stoichiometry in an ecological context: testing for links between Daphnia P-content, growth rate and habitat preference. Oecologia142:20-27.

Dumont HJ, Carels I, 1987. Flatworm predator (Mesostoma $\mathrm{cf}$. lingua) releases a toxin to catch planktonic prey (Daphnia magna). Limnol. Oceanogr. 32:699-702.

Dumont HJ, Schorreels S, 1990. A laboratory study of the feeding of Mesostoma lingua (Schmidt) (Turbellaria: Neorhabdocoela) on Daphnia magna Straus at four different temperatures. Hydrobiologia 198:61-77.

Dumont HJ, Rietzler AC, Han BP, 2014. A review of typhloplanid flatworm ecology, with emphasis on pelagic species. Inland Waters 4:257-270.

Dunkel J, Talbot J, Schötz EM, 2011. Memory and obesity affect the population dynamics of asexual freshwater planarians. Physical Biol. 8:026003.

Dutilleul P, 1993. Modifying the $t$ test for assessing the correlation between two spatial processes. Biometrics 49:305-314.

Egger B, Gschwentner R, Rieger R, 2007. Free-living flatworms under the knife: past and present. Dev. Genes Evol. 217:89-104.

Gilinsky E, 1984. The role of fish predation and spatial heterogeneity in determining benthic community structure. Ecology 65:455-468.

Gulati RD, Bronkhorst M, Van Donk E, 2001. Feeding in Daphnia galeata on Oscillatoria limnetica and on detritus derived from it. J. Plankton Res. 23:705-718.

Hammill E, Kratina P, Vos M, Petchy OL, Anholt BR, 2015. Food web persistence is enhanced by non-trophic interactions. Oecologia 178:549-556.

Iyer N, Rao TR, 1996. Responses of the predatory rotifer $A s-$ planchna intermedia to prey species differing in vulnerability: laboratory and field studies. Freshwater Biol. 36: 521-533.

Kolasa J, Tyler S, 2010. Flatworms: Turbellaria and Nemertea, p. 145-172. In: J.H. Thorp and A.P. Covich (eds.), Ecology and classification of North American freshwater invertebrates. Academic Press, San Diego.

Kratina P, Vos M, Bateman A, Anholt BR, 2009. Functional responses modified by predator density. Oecologia 159:425-433.

Krebs CJ, 1999. Ecological methodology. Addison Wesley Longman Inc., New York: 654 pp.

Lampert W, Sommer U, 2007. Limnoecology: the ecology of lakes and streams. Oxford University Press, New York.

Martinez DE, Levinton JS, 1992. Asexual metazoans undergo senescence. PNAS 89:9920-9923.

Mohr S, Adrian R, 2002. Reproductive success of the rotifer Brachionus calyciflorus feeding on ciliates and flagellates of different trophic modes. Freshwater Biol. 47:1832-1839.

Mouton S, Willems M, Back P, Braeckman BP, Borgonie G, 2009. Demographic analysis reveals gradual senescence in the flatworm Macrostomum lignano. Front. Zool. 6:1-7.

Murdoch WW, Bence J, 1987. General predators and unstable prey populations, p. 538-554. In W.C. Kerfoot and A. Sih (eds.), Predation: direct and indirect impacts on aquatic com- munities. University Press of New England, Hanover.

Nandini S, Sarma SSS, 2005. Life history characteristics of $\mathrm{As}$ planchnopus multiceps (Rotifera) fed rotifer and cladoceran prey. Hydrobiologia 546:491-501.

Nandini S, Sarma SSS, Dumont HJ, 2011. Predatory and toxic effects of the turbellarian (Stenostomum cf leucops) on the population dynamics of Euchlanis dilatata, Plationus patulus (Rotifera) and Moina macrocopa (Cladocera). Hydrobiologia 662:171-177.

Newmark PA, Alvarado AS, 2000. Bromodeoxyuridine specifically labels the regenerative stem cells of planarians. Dev. Biol. 220:142-153.

Noreña C, Damborenea C, Brusa F, 2005. A taxonomic revision of South American species of the genus Stenostomum O. Schmidt (Platyhelminthes: Catenulida) based on morphological characters. Zool. J. Linn. Soc. 144:37-58.

Perhar G, Arhonditsis GB, 2009. The effects of seston food quality on planktonic food web patterns. Ecol. Model. 220:805-820.

Petersen CP, Reddien PW, 2008. Smed- $\beta$ catenin-1 is required for anteroposterior blastema polarity in planarian regeneration. Science 319:327-330.

Reuter M, Kreshchenko N, 2004. Flatworm asexual multiplication implicates stem cells and regeneration. Can. J. Zool. 82:334-356.

Rico-Martínez R, Snell TW, 1997. Mating behavior in eight rotifer species: using crossmating tests to study species boundaries. Hydrobiologia 356:165-173.

Reddien PW, Alvarado AS, 2004. Fundamentals of planarian regeneration. Ann. Rev. Cell Dev. Biol. 20:725-757.

Schwartz SS, Hebert PDN, 1982. A laboratory study of the feeding behavior of the rhabdocoel Mesostoma ehrenbergii on pond Cladocera. Can. J. Zool. 60:1305-1307.

Sterner RW, Hessen DO, 1994. Algal nutrient limitation and the nutrition of aquatic herbivores. Annu. Rev. Ecol. Syst. 25:1-29.

Sarma SSS, Rao T, 1991. The Combined Effects of Food and Temperature on the Life History Parameters of Brachionus patulus Muller (Rotifera). Int. Rev. Ges Hydrobiol. 76:225-239.

Threlkeld ST, 1994. Benthic-pelagic interactions in shallow water columns: an experimentalist's perspective. Hydrobiologia 275-276:293-300.

Trexler JC, McCulloch CE, Travis J, 1988. How can the functional response best be determined? Oecologia 76:206-214.

Trochine C, Modenutti B, Balseiro E, 2006. Influence of spatial heterogeneity on predation by the flatworm Mesostoma ehrenbergii (Focke) on calanoid and cyclopoid copepods. J. Plankton Res. 28: 67-274.

Véra A, Desvilettes C, Bec A, Bourdier G, 2001. Fatty acid composition of freshwater heterotrophic flagellates: an experimental study. Aquat. Microb.1 Ecol. 25:271-279.

Wacker A, Martin-Creuzburg D, 2007. Allocation of essential lipids in Daphnia magna during exposure to poor food quality. Funct. Ecol. 21:738-747.

Weber CI, 1993. Methods for measuring the acute toxicity of effluents and receiving waters to freshwater and marine organisms, 4th ed. U.S. Environmental Protection Agency, Cincinnati, OH, USA.

Werner EE, Hall DJ, 1976. Niche shifts in sunfishes: experimental evidence and significance. Science 191:404-406. 